\title{
Influence of season, age and breed on prevalence of haemoprotozoan diseases in cattle of Tamil Nadu, India
}

\author{
R. Velusamy, N. Rani, G. Ponnudurai, T. J. Harikrishnan, T. Anna, K. Arunachalam, K. Senthilvel and P. Anbarasi
}

Department of Veterinary Parasitology,

Veterinary College and Research Institute, Tamil Nadu Veterinary and Animal Sciences University (TANUVAS), Namakkal - 637 002, Tamil Nadu, India.

Corresponding author: R. Velusamy, email: velupara@yahoo.com, Telephone: +91-9488957030.

NR: ranivetpara@rediffmail.com, GP: Ponnuvet@gmail.com, TJH: tjkrish@rediffmail.com, TA: tanna@rediffmail.com, KA: hemacha@rediffmail.com, KS: kansen@rediffmail.com, PA: anbuvet@yahoo.com

Received: 20-04-2014, Revised: 24-06-2014, Accepted: 01-07-2014, Published online: 08-08-2014

doi: 10.14202/vetworld.2014.574-578 How to cite this article: Velusamy R, Rani N, Ponnudurai G, Harikrishnan TJ, Anna T, Arunachalam K, Senthilvel K and Anbarasi P (2014) Influence of season, age and breed on prevalence of haemoprotozoan diseases in cattle of Tamil Nadu, India, Veterinary World 7(8): 574-578.

\begin{abstract}
Aim: To assess the prevalence of haemoprotozoan diseases in cross-bred and indigenous cattle in relation to season, age and breed in Western part of Tamil Nadu, India.

Materials and Methods: A total of 2637 blood smears were screened for haemoprotozoan diseases and samples were received from the college hospital and veterinary dispensaries in Western part of Tamil Nadu, India. Blood smears were stained using Giemsa's technique and examined under oil immersion.

Results: Microscopic examination of blood smears revealed an overall prevalence of $16.64 \%$; of which theileriosis was $13 \%$, followed by anaplasmosis $2.64 \%$ and then babesiosis $1.0 \%$. Among the haemoprotozoan diseases, the prevalence of theileriosis was significantly $(\mathrm{p}<0.05)$ high during summer $(14.4 \%)$, followed by moderate in monsoon $(13.8 \%)$ and less in fair $(11.5 \%)$ seasons. However, there was no significant seasonal influence on the prevalence of babesiosis and anaplasmosis. The data on influence of breed revealed that there was a significantly $(\mathrm{p}<0.05)$ high prevalence of haemoprotozoan diseases in Holstein Friesian (HF) and Jersey cross breeds than indigenous breed and the occurrence of these haemoprotozoan diseases was found to be high among the age groups of 2-7 years in cross-bred animals and below 2 years in indigenous animals.
\end{abstract}

Conclusion: The present study suggests that Western part of Tamil Nadu is highly endemic for theileriosis and occurrence of the disease was high during summer. Cross-bred animals aged 2-7 years are highly susceptible to these haemoprotozoan diseases than indigenous animals.

Keywords: anaplasmosis, babesiosis, cattle, prevalence, theilerisosis.

\section{Introduction}

Haemoprotozoan infections are very common in cattle and cause devastating losses to the livestock industry and pose a major threat to the dairy industry throughout the world [1]. Most of the haemoprotozoan parasites are transmitted by ticks and is of great economic importance in Asia and has always been a formidable barrier to the survival of exotic and cross bred cattle in India [2]. The hot and humid climate is very conducive for the development and survival of potential vectors such as ticks and flies and is a constant source of infection to susceptible animals [3]. Theileriosis, babesiosis and anaplasmosis are the three major tick borne haemoprotozoan diseases of crossbred cattle in tropical and sub-tropical regions of the world $[4,5,6]$. In India, the annual loss estimated due to tropical theileriosis alone is approximately US \$ 800 million [7]. In the absence of adequate control measures, these haemoprotozoan diseases have serious economic impact on cattle production in terms of

Copyright: The authors. This article is an open access article licensed under the terms of the Creative Commons Attribution License (http://creativecommons.org/licenses/by/2.0) which permits unrestricted use, distribution and reproduction in any medium, provided the work is properly cited.

Veterinary World, EISSN: 2231-0916 mortality, reduced milk yield and lowered draft power.

In India, haemoptozoan diseases have been reported from different geographical regions. The incidence of theileriosis was found to be $27.2 \%$ in cross-bred cattle with highest prevalence rate of $45.4 \%$ during rainy season in Dehradun district, Uttarakhand, India [8]. The overall incidences of haemoprotozoan diseases viz., theileriosis (37\%), babesiosis (10.41\%), anaplasmosis $(2.82 \%)$ was recorded in cross bred cattle in Anand district of Gujarat, India [9]. In Northern Kerala, theileriosis and babesiosis have been reported as $16 \%$ and $0.6 \%$, respectively in crossbred cattle [10]. An outbreak of theileriosis in cattle has been reported from Punjab with $4.86 \%$ mortality rate [11].

To undertake effective preventive measures, disease forecasting system must be in place, for which the pattern of disease occurrence in the past years at least 10 years are to be studied. The present study was aimed to find out the prevalence of haemoprotozoan diseases in cross-bred cattle in relation to season, age and breed in Western part of Tamil Nadu, India.

\section{Materials and Methods}

Study area: Blood smears were received from the college hospital and veterinary dispensaries in and 
Table-1: Seasonal pattern of blood protozoan in cattle recorded from January' 2003 to December' 2012 in Namakkal area.

\begin{tabular}{|c|c|c|c|c|c|c|}
\hline Season & Month & $\begin{array}{l}\text { Number of blood } \\
\text { smear examined }\end{array}$ & Theileriosis & Babesiosis & Anaplasmosis & $\begin{array}{l}\text { Total no. } \\
\text { of positive }\end{array}$ \\
\hline Summer & $\begin{array}{l}\text { March } \\
\text { April } \\
\text { May } \\
\text { June }\end{array}$ & $\begin{array}{l}230 \\
239 \\
299 \\
216\end{array}$ & $\begin{array}{l}32 \\
41 \\
32 \\
37\end{array}$ & $\begin{array}{l}8 \\
1 \\
1 \\
1\end{array}$ & $\begin{array}{c}10 \\
4 \\
6 \\
5\end{array}$ & $\begin{array}{l}50 \\
46 \\
39 \\
38\end{array}$ \\
\hline Total & & 984 & $142(14.4 \%)$ & $11(1.1 \%)_{\text {NS }}$ & $25(2.5 \%)$ & $178(18 \%)$ \\
\hline $\begin{array}{l}\text { Mean } \pm \text { S.E } \\
\text { Rainy }\end{array}$ & $\begin{array}{c}\text { July } \\
\text { August } \\
\text { September } \\
\text { October }\end{array}$ & $\begin{array}{l}234 \\
229 \\
204 \\
215\end{array}$ & $\begin{array}{c}35.50 \pm 2.17^{\mathrm{a}} \\
34 \\
36 \\
28 \\
24\end{array}$ & $\begin{array}{c}2.75 \pm 1.75 \\
2 \\
4 \\
3 \\
3\end{array}$ & $\begin{array}{c}6.25 \pm 1.31 \\
4 \\
8 \\
3 \\
7\end{array}$ & $\begin{array}{l}40 \\
48 \\
34 \\
34\end{array}$ \\
\hline $\begin{array}{l}\text { Total } \\
\text { Mean } \pm \text { S.E }\end{array}$ & & 882 & $\begin{array}{c}122(13.8 \%) \\
30.50 \pm 2.75^{a b}\end{array}$ & $\begin{array}{c}12(1.36 \%) \\
3.00 \pm 0.40^{\mathrm{NS}}\end{array}$ & $\begin{array}{c}22(2.4 \%) \\
5.50 \pm 1.90^{\mathrm{NS}}\end{array}$ & $156(17.68 \%)$ \\
\hline $\begin{array}{l}\text { Total } \\
\text { Mean } \pm \text { S.E }\end{array}$ & $\begin{array}{c}\text { November } \\
\text { December } \\
\text { January } \\
\text { February }\end{array}$ & $\begin{array}{l}185 \\
222 \\
175 \\
184 \\
776\end{array}$ & $\begin{array}{c}19 \\
37 \\
17 \\
16 \\
89(11.5 \%) \\
22.25 \pm 4.95^{b}\end{array}$ & $\begin{array}{c}2 \\
3 \\
2 \\
2 \\
9(1.0 \%) \\
2.25 \pm 0.25^{\mathrm{NS}}\end{array}$ & $\begin{array}{c}4 \\
4 \\
2 \\
2 \\
12(1.5 \%) \\
3.00 \pm 0.577^{\mathrm{NS}}\end{array}$ & $\begin{array}{c}25 \\
44 \\
21 \\
20 \\
110(14.1 \%)\end{array}$ \\
\hline
\end{tabular}

Mean with similar superscript in a column do not differ significantly $(p \geq 0.05)$.NS-Non significant.

around Namakkal area, which is located in Western part of Tamil Nadu. The geographical location of the study lies between 11.00 and 11.360 North latitude and 77.280 and 78.300 East longitude and witnessed a temperature range of $35-38^{\circ} \mathrm{C}$ with maximum of $42^{\circ}$ $\mathrm{C}$, relative humidity of $57-55 \%$ and rain fall about 1$4 "$. The season in this area can be broadly classified into hot and dry summer from March to June, monsoon season from July to October and the winter season from November to February.

Study period: The data recorded in the specimen register of department of Veterinary Parasitology were compiled and analysed for a period of 10 years from January 2003 to December 2012 (Figure-1).

Sample size: A total of 2637 blood smears were received from Veterinary College and Research Institute Hospital, Namakkal and Veterinary dispensaries in different places of Western Tamil Nadu.

Blood smear examination: Thin blood smears were fixed in methanol (5 minutes) and stained with Giemsa's stain (30 minutes) and were examined under oil immersion lens (100X magnification) for presence of blood parasites. The parasites were identified on the basis of characteristic morphology. Even the presence of a few piroplasms was considered to be positive. Parasitaemia in positive cases was graded as mild or severe by counting at least 10 randomly chosen oil immersion fields (Figure-2).

Statistical analysis: Data were statistically analysed using one-way analysis of variance (ANOVA) (SPSS software version 17) at $p<0.05$ regarded as statistically significant [12]. All the values were expressed as mean and standard error of mean (SEM) and Microsoft excel was used for presentation of the results.

\section{Results}

The analysis of data on the prevalence of haemo- protozoan parasites of cattle in Western part of Tamil Nadu for the period from 2003-2012 showed an overall prevalence of $16.64 \%$. Of which, theileriosis was $13 \%$ followed by anaplasmosis $2.64 \%$ and then babesiosis $1.0 \%$. Among the haemoprotozoan diseases, the prevalence of tropical bovine theileriosis was found to be high, followed by anaplasmosis and babesiosis (Figure-1). It is important to note that, the prevalence of theileriosis has reached peak in the year 2004 and 2007 and also a similar trend was observed with anaplasmosis in the same period. Conversely, there was no fluctuation in the prevalence of babesiosis.

The prevalence of theileriosis was significantly $(\mathrm{p}<0.05)$ high during summer $(14.4 \%)$, followed by moderate in monsoon $(13.8 \%)$ and less in fair $(11.5 \%)$ seasons (Table-1). However, there was no significant seasonal influence on the prevalence of babesiosis and anaplasmosis.

Screening of breed wise prevalence data revealed that there was a significantly $(\mathrm{p}<0.05)$ high prevalence of haemoprotozoan diseases in Holstein Friesian (HF) and Jersey cross breeds than indigenous breed (Table2) and the occurrence of these haemoprotozoan diseases was found to be high among the age groups of 2-7 years in cross-bred animals and below 2 years in indigenous animals.

\section{Discussion}

Our retrospective study revealed that $16.64 \%$ of cattle were found infected with haemoprotozoan parasites viz., Theileria annulata, Anaplasma marginale and Babesia bigemina as single or mixed infections. Among the haemoprotozoan diseases, the prevalence of theileriosis was found to be high (13\%), followed by anaplasmosis (2.64\%) and babesiosis (1.0\%). In India, theieriosis is a fatal parasitic disease and has been reported from various geographical regions of the country and recorded as $21.1 \%$ in Tamil Nadu [13], 
Table-2: Age and breed wise prevalence of blood protozoan in cattle recorded from January' 2003 to December' 2012 in Namakkal area.

\begin{tabular}{|c|c|c|c|c|c|c|c|c|c|c|c|}
\hline \multirow[t]{3}{*}{ Year } & \multirow{3}{*}{$\begin{array}{l}\text { Numbers of blood } \\
\text { smear examined }\end{array}$} & \multirow{3}{*}{$\begin{array}{c}\text { No. of positive } \\
\text { cases }\end{array}$} & \multicolumn{9}{|c|}{ Breed } \\
\hline & & & \multicolumn{3}{|c|}{ HF Cross, Age (Years) } & \multicolumn{3}{|c|}{ Jersey, Age (Years) } & \multicolumn{3}{|c|}{ ND, Age (Years) } \\
\hline & & & $2-4$ & $5-7$ & $8-10$ & $2-4$ & $5-7$ & $8-10$ & $0-4$ & $5-7$ & $8-10$ \\
\hline 2003 & 201 & 41 & 10 & 19 & 0 & 4 & 8 & 0 & 0 & 0 & 0 \\
\hline 2004 & 217 & 71 & 17 & 18 & 0 & 17 & 19 & 0 & 0 & 0 & 0 \\
\hline 2005 & 418 & 88 & 20 & 19 & 5 & 20 & 19 & 4 & 1 & 0 & 0 \\
\hline 2006 & 231 & 50 & 14 & 9 & 0 & 11 & 15 & 0 & 1 & 0 & 0 \\
\hline 2007 & 256 & 66 & 17 & 15 & 1 & 16 & 16 & 1 & 0 & 0 & 0 \\
\hline 2008 & 216 & 29 & 9 & 5 & 1 & 6 & 4 & 3 & 1 & 0 & 0 \\
\hline 2009 & 315 & 34 & 7 & 11 & 2 & 5 & 6 & 2 & 1 & 0 & 0 \\
\hline 2010 & 348 & 22 & 5 & 8 & 1 & 2 & 5 & 1 & 0 & 0 & 0 \\
\hline 2011 & 271 & 18 & 3 & 4 & 1 & 2 & 1 & 6 & 1 & 0 & 0 \\
\hline 2012 & 164 & 20 & 7 & 2 & 0 & 7 & 3 & 1 & 1 & 0 & 0 \\
\hline Total & 2637 & 439 & 109 & 110 & 11 & 90 & 95 & 18 & 6 & 0 & 0 \\
\hline \multicolumn{3}{|c|}{ Mean \pm S.E } & \multicolumn{3}{|c|}{$23.00 \pm 3.74^{\mathrm{a}}$} & \multicolumn{3}{|c|}{$20.40 \pm 4.07^{a}$} & \multicolumn{3}{|c|}{$6.67 \pm 0.16^{b}$} \\
\hline
\end{tabular}

Mean with similar superscript in a column do not differ significantly $(p \geq 0.05)$.

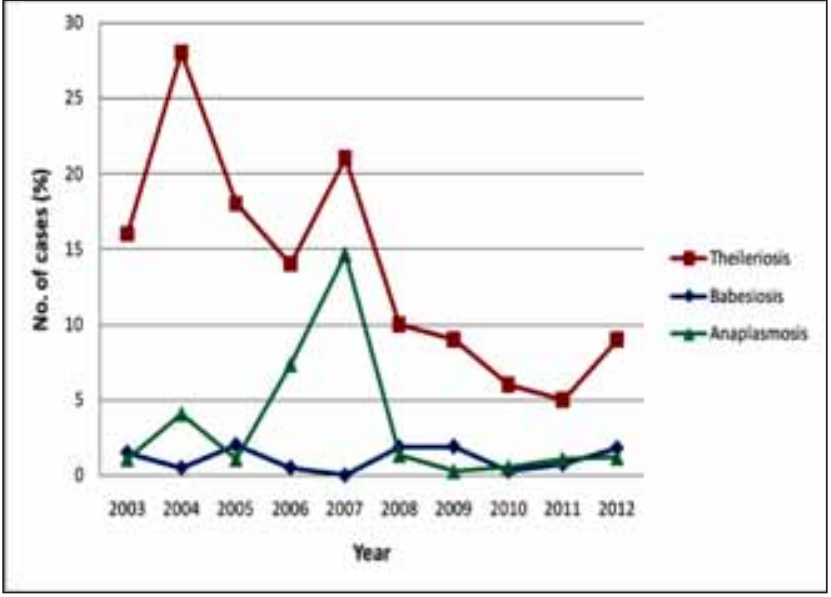

Figure-1: Prevalence of haematoprotozoan diseasee in cattle recorded from January 2003 to December 2012 in and around Namakkal area.

$16 \%$ in Northern Kerala [10], 17.7\% in Karnataka [14], $45.4 \%$ in Dehradun, Uttarakhand [8] and $4.86 \%$ in Punjab [11]. These differences observed in the prevalence may be due to the different geographical locations of the study areas, time periods and various methods of sample analysis. It is interesting to note in the present study that an increased number of concurrent infections of theileriosis and anaplasmosis in the same period may be due to involvement of same species of ticks (probably Hyalomma spp.) in the transmission of both the haemoprotozoan diseases. Besides, Hyalomma spp. is the most common species of tick infesting cattle in Southern part of India $[15,16]$ than Boophilus spp. [17], which involves in the transmission of babesiosis. This could be the reason why low incidence of babesiosis was observed in this part of Tamil Nadu.

Haemoprotozoan infection, particularly Theileria spp. infection reached peak during 2003 and then started declining (Figure-1). This could be due to regular usage of chemical control programme particularly the application of Deltamethrin ( $0.2 \%$ Butox $)$ as a spray on animals and cattle shed which reduced the tick population under field conditions. The slow rise of Theileria infection during 2012 might be due to low rainfall and high temperature which favoured propa-

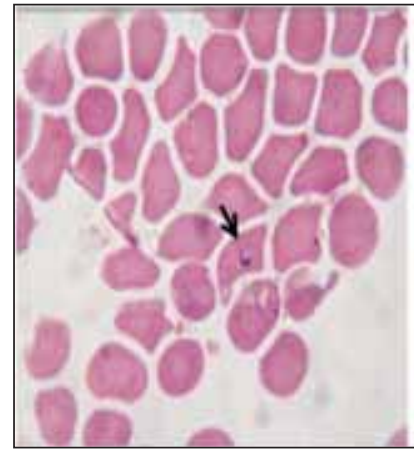

Mild (+)

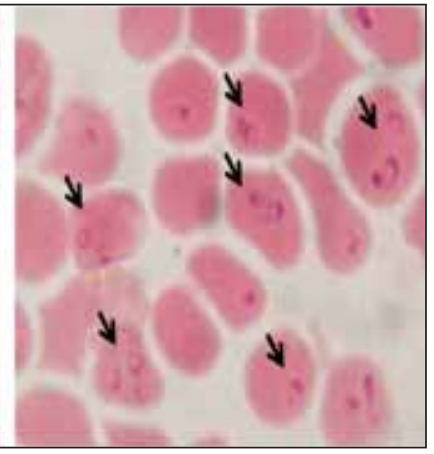

Severe $(++++)$
Figure-2: Microscopic examination of Giemsa stained blood smear showing piroplasm of Theileria parasite (arrow shows the piroplasm stage of Theileria spp. in erythrocyte).

gation of tick vector and in turn actively involved in the transmission of haemoprotozoan parasites (Figure-1).

An effort that was made to know the influence of seasonal variation on the prevalence of haemoprotozoan diseases, theileriosis was found to be significantly high during summer (14.4\%), followed by moderate in monsoon (13.8\%) and less in fair seasons (11.5\%). The present investigation is in conformity with the report from Ranchi, Bihar [18], a high prevalence of theileriosis was observed during summer (17.64\%), followed by rainy $(7.32 \%)$ and less in winter $(5 \%)$. On contrary, a few reports of higher prevalence of theileriosis were observed during monsoon season $[9,19,20]$. The high prevalence of theileriosis observed in the present study may be due to high abundance of tick vector, because high temperature and humidity is ideal for survival and breeding of ticks $[21,22]$. While studying the prevalence of babesiosis, it was recorded that highest prevalence during rainy season followed by summer and winter $[23,24]$, but in the present study, there was no such seasonal influence on babesiosis and anaplamosis. A considerable seasonal variation with respect to the occurrence of the haemoprotozoan disease may be due to changes in macroclimate that is essential for breeding of ticks. 
In the present study, screening of breed wise prevalence data revealed that cross-bred animals were mostly affected than indigenous animals. Breed susceptibility in this study are in line with observation made in crossbred cattle of Bangalore North [25]. Further, it was observed in the present study that the occurrence of these haemoprotozoan diseases were found to be high among the age groups of 2-7 years in both the cross breeds and below 2 years in indigenous animals. This study supports the report witnessing animals over 3 years of age are highly affected by haemoprotozoan diseases in cross-bred animals [26]. On contrary, the occurrence of babesiosis was found even in 15 days to 6 months old calf in this study. This made to suggest that inverse age resistance may fail to protect if there is any problem in maternal antibodies. Most of the cross-bred animals aged around 7 years were in the stage of $3^{\text {rd }}$ or $4^{\text {th }}$ lactation as peak milk yielders. The weakening of immunity during high milk yielding stage in addition to genetic make up and seasonal stress in summer months could be reason for high susceptibility to this haemoprotozoan parasite.

\section{Conclusion}

The present study suggests that Western part of Tamil Nadu is highly endemic for theileriosis and occurrence of the disease was high during summer. Cross-bred animals, aged 2-7 years are highly susceptible to these haemoprotozoan diseases than indigenous animals.

\section{Recommendation}

The outcome of the present study would help to forecast disease outbreak not only in this region but also applicable to other parts of country. There is a need for further investigations using molecular techniques for the accurate identification of the carrier status of haemoprtozoan parasites.

\section{Authors' contributions}

RV, NR, GP, TJ, TA, KA, KS and PA-blood smear examination and identification of parasites. RV and GP-preparation of manuscript and analysis of data. All authors read and approved the manuscript.

\section{Acknowledgements}

The authors are grateful to the staff who had contributed their valuable data for this study during their tenure in this department and also we sincerely extend our gratitude to the Dean, Veterinary College and Research Institute, Namakkal for the facilities provided. The authors are thankful to Tamil Nadu Veterinary and Animal Sciences University, India for providing financial support throughout the study period.

\section{Competing interests}

The authors declare that they have no competing interests.

\section{References}

1. Shahnawaz, S., Ali, M., Aslam, M.A., Fatima, R.,
Chaudhry, Z.I., Hassan, M.U., Ali, M. and Iqbal, F. (2011) A study on the prevalence of a tick transmitted pathogen, Theileria annulata, the hematological profile of cattle from Southern Punjab (Pakistan). Parasitol. Res., 109: 11551160.

2. Soundararajan, C. and Rajavelu, G. (2006) Prevalence of haemoprotozoan among cattle and buffaloes. Indian Vet. J., 83: $1258-1260$

3. Chowdhury, S., Hossain, M.A., Barua, S.R., and Islam S. (2006) Occurrence of common blood parasites of cattle in Sirajgonj Sadar area of Bangladesh. Bangladesh J. Vet. Med., 4(2):143-145.

4. Parthiban, M.,Saranya, R., Mahesh, M., and Raman, M. (2010) Detection of Theileria parasite in cattle of Tamil Nadu using nested PCR. Tamil Nadu J. Vet. Anim. Sci., 6(4):162-165.

5. Lurthu Reetha,T., Shibi Thomas, K. and Babu, M. (2012) Occurrence of haemoprotozoan infection in bovines. Int. J. Appl. Bioresearch, 13:1-2.

6. Arunkumar, S. and Nagarajan, K. (2013) A study on prevalence status of Anaplasma marginale infection among cattle population of Kancheepuram and in and around Chennai districts of Tamil Nadu. Int. J. Food Agri. and Vet. Sci., 3:155-157.

7. Project directorate on animal disease monitoring and surveillance Annual report (2005) Indian Council of Agricultural Research, New Delhi.

8. Kohli, S., Atheya, U.K. and Thapliyal, A. (2014) Prevalence of theileriosis in cross-bred cattle: its detection throughblood smear examination and polymerase chain reaction in Dehradun district, Uttarakhand, India. Vet. World, 7(3): 168171.

9. Vahora, S. P., Patel, J. V., Parel, B. B., Patel S. B., Umale, R. H. (2012) Seasonal incidence of haemoprotozoan diseases in crossbred cattle and buffalo in Kaira and Anand district of. Gujarat, India. Vet. World, 5 (4): 223-225.

10. Nair, A.S., Ravindran, R., Lakshmanan, B., Kumar, S.S.,Tresamol, P.V., Saseendranath, M.R.,Senthilvel, K., Rao,J.R., Tewari, A.K. and Ghosh, S. (2011) Haemoprotozoan of cattle in Northern Kerala, India. Trop. Biomed., 28(1): 68-75.

11. Mahajan, V., Gupta, M.P., Bal, M.S., Kumar, H., Mittal, D., Filia, G., Sharma, S., Banga, H.S., Kaur, K., Singla, L.D., Verma, S., Ashuma and Sandhu, K.S. (2013) Outbreaks of theileriosis in cattle in Punjab. Indian Vet. J., 90: 77-78.

12. GraphPad Software Instat (2003) Guide to choosing and Maiduguri, Borno State. Centre for Research and interpreting statistical tests. GraphPad software Inc. Innovations. 3: 6-11.

13. Anandan, R., Lalitha John, M., Ganesamurthy, M. and Lalitha, C. M. (1989) Paper presented in the National Seminar at Department of Animal Disease Investigation and Control, Madras Veterinary College, Madras from 20.9.89 to 21.9.89.

14. Muraleedharan, K., Ziauddin, K. S., Hussain, P. M., Seshadri, S. J., Mallika Arjun, G. B. and Puttabyatappa, B. (1994) Observations on theilerial infection of cattle in project area of Mysore cooperative milk producer's union, Karnataka state. Cheiron, 23 (3):130-139.

15. Ponnudurai,G., Harikrishnan, J. and Rani, N.(2013) Bionomics of ixodid ticks of ruminants in Namakkal, Tamil Nadu, India. Indian J. Anim. Sci., 83(4): 71-73.

16. Latha, B.R., Aiyasami, S.S., Pattabiraman,G., Sivaraman,T. and Rajavelu, G.(2004) Seasonal activity of ticks on small ruminants in Tamil Nadu state, India. Trop. Anim. Health Prod., 36: 123-133.

17. Koshy, T.J., Rajavelu, G. and Lalitha, C.M. (1982) Ecology and binomics of Boophilids of Tamil Nadu. Cheiron, 11: 2530 .

18. Chakraborty, U. (1993) Prevalence of theileriosis in cattle in Ranchi. M.V.Sc., Thesis submitted in Birsa agricultural university, Ranchi. 
19. Radostits, O. M., Blood, D. C. and Gay, C. C. (1994) A text book of the diseases of cattle, sheep, Goats, Pigs and Horse. 8th ed., ELBS, Baillier, Tindall, London, p365-367.

20. Roy, S., Tiwari, A., Galdhar, C. N., Upadhyay, S. R., Ratre, H. K., Sahu, S. K., and Maiti, S. K. (2004) Seasonal prevalence of haemoprotozoan diseases in cross- bred cattle and buffaloes. Indian J. Vet. Med., 24:5-7.

21. Magona, J.W., Walubengo, J., Olaho-Mukani, W., Jonsson, N.N., Welburn, S.W. and Eisler, M.C. (2011) Spatial variation of tick abundance and seroconversion rates of indigenous cattle to Anaplasma marginale, Babesia bigemina and Therileria parva infections in Uganda. Exp. Appl.Acarol., 55: 203-213.

22. Haque,M., Jyoti, Singh, N.K. and Rath, S.S. (2010)
Prevalence of Theileria annulata infection in Hyalomma anatolicum in Punjab state, India. J.Parasit.Dis., 34 (1) 4851.

23. Bhikane, A. U., Narladkar, B., Anantwar, L. G. and Bhokre, A. P. (2001). Epidemiology, clinic-pathology and treatment of babesiosis in cattle. Indian Vet. J., 78 (8):723-725.

24. Pallav Shekar and Haque, S. (2007) Epidemiology of blood protozoan diseases of cattle in Jharkand. Indian Vet. J., 84 (10):1039-1041.

25. Ananda, K. J., D'Souza, P. E. and Puttalakshmamma, G. C. (2009) Prevalence of Haemoprotozoan diseases in crossbred cattle in Bangalore north. Vet. World, 2 (1):15-16.

26. Chakraborti, A. (2002) A textbook of Preventive Veterinary Medicine. $3^{\text {rd }}$ ed., Kalyani Publishers, New Delhi, p683.

$* * * * * * * *$ 